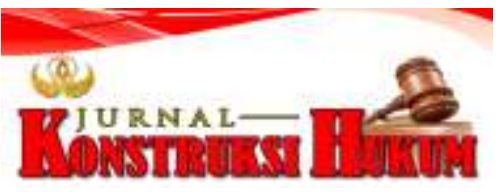

\title{
PERLINDUNGAN HUKUM TERHADAP NASABAH DALAM PENUNDAAN KREDIT TERDAMPAK COVID 19
}

\author{
Sang Nyoman Angga, Ni Luh Made Mahendrawati, Ni Made Puspasutari Ujianti \\ Fakultas Hukum Universitas Warmadewa, Denpasar-Bali, Indonesia \\ sangnyoman@gmail.com, mademahendrawatigmail.com, puspasutariujiantigmail.com
}

\begin{abstract}
Abstrak
Manusia sebagai makhluk sosial yang hidup berdampingan serta memiliki berbagai kebutuhan yang harus dipenuhi demi bisa bertahan hidup. Dalam pernenuhan kebutuhan tersebu. Indonesia sering melakukan pembayaran dengan sistem kredit. Kredit merupakan sesuatu terobosan yang sangat mebantu masyarakat. Namun dengan adanya Pandemi Covid-19) memukul berbagai dunia usaha dan nasabah pembiayaan kredit karena ber kurangnya pendapatan. Penelitian ini bertujuan untuk menelaah pengaturan hukum penundaan kredit terhadap nasabah yang terdampak covid 19 di Indonesia dan menjelaskan perlindungan hukum terhadap nasabah yang terdampak cosvid 19 di Indonesia. Jenis penelitian yang diterapkan dalam penelitian ini yaitu penelitian hukum normatif, dengan pendekatan Perundang-undangan dan pendekatan konsep. Secara umum pengaturan penundaan kredit terhadap nasabah terdampak covid 19 diatur dalam POJ K Nomor II POJK.03 2020 tentang stimulus perekonomian nasional sebagai kebijakan counterc helical dampak penyebaran coronavirus disease 2019. Perlindungan hukumnya ada dua yakni perlindungan hukum preventif dengan menerbitkan PERPU Nomor I Tahun 2020 tentang kebijakan keuangan negara dan stabilitas untuk penanganan pandemi coronavirus disease 19, dan Perlindungan hukum represif berpedoman pada Surat Edaran Bank Indonesia No. 26/4/BPPP yang pada prinsipnya mengatur penyelamatan kredit bermasalah melalui rescheduling, Reconditioning, restru kturisasi.
\end{abstract}

Kata Kunci: Covid 19, Kredit, Perlindungan Hukum

\section{Abstract}

Humans as social beings who live side by side and have various needs that must be met in order to survive. In meeting these needs. Indonesia often makes payments with a credit system. Credit is a breakthrough that really helps the community. However, with the Covid-19 Pandemic) hitting various businesses and credit financing customers due to lack of income. This study aims to examine the legal arrangements for credit delays for customers affected by COVID-19 in Indonesia and explain legal protection for customers affected by COVID19 in Indonesia. The type of research applied in this research is normative legal research, with a statutory approach and a concept approach. In general, the regulation of credit delays for customers affected by COVID-19 is regulated in POJ K Number II POJK.03 2020 regarding the national economic stimulus as a counter-helical policy for the impact of the 2019 coronavirus disease. There are two legal protections, namely preventive legal protection by issuing PERPU Number I of 2020 concerning state financial policies and stability for handling the coronavirus disease 19 pandemic, and repressive legal protection based on Bank Indonesia Circular Letter No. 26/4/BPPP which in principle regulates the rescue of non-performing loans through rescheduling, reconditioning, restructuring.

Keywords: Covid 19, Credit, Legal Protection

\section{PENDAHULUAN}

Undang- undang Dasar Negara Republik 1ndonesia Tahun 1945 dalam pasal I ayat (3) menyatakan bahwa Indonesia sebagai negara hukum. Dengan adanya penegasan tersebut mengandung makna bahwa setiap tindakan yang dilakukan oleh negara maupun warga negara harus berlandaskan dan berdasarkan atas hukum (Suputra et al., 2017). Selain dikenal sebagai Negara hukum Negara Indonesia juga dikenal sebagai Negara yang masuk ke dalam golongan negara berkembang yang masih perlu melaksanakan pembangunan disegala bidang demi bisa meningkatkan perekonomian bangsa serta menjamin kesejahteraan rakyatnya (Hairi, 2018). Kemajuan perekonomian memang harus dilakukan sebagai upaya memperbaiki taraf hidup masyarakat Indonesia sebagaimana yang tenuang dalam Undang-undang Dasar Negara Republik Indonesia Tahun 1945, khususnya untuk meningkatkan bantuan pemerintah kepada rakyat Indonesia secara adil. Untuk meningkatkan 
bantuan pemerintah daerah setempat, penting untuk memiliki aset atau kantor, misalnya pemberian kredit dengan syarat yang memadai atau bantuan modal (Yantie et al., 2017). Ada berbagai jenis kredit, baik uang muka rumah, uang muka tanah, dan uang muka transportasi. Selain itu, seiring dengan berkembangnya zaman cara hidup daerah setempat beru batt, dimana terdapat keinginan daerah setempat untuk mendapatkan kantor penunjang kehidupan yang memadai, termasuk transportasi. Saat ini, orang semakin cenderung membeli kendaraan mekanis karena cenderung diselesaikan dengan cara kredit, selain dari cicilan sedikit dibayar dimuka, perusahaan kredit juga memudahkan orang untuk membeli kendaraan bermotor. Kemudahan yang diberikan oleh perusahaan pembiayaan telah sejauh ini telah mampu memberikan pembiayaan kendaraan bermotor dan mendorong peningkatan derajat pemanfaatan dalam kehidupan masyarakat di Indonesia. Sebelum masa pandemic covid 19 masyarakat di Indonesia bergerak dalam berbagai usaha dengan hasil yang cukup menjanjikan seperti bergerak di sektor pariwisata, bergerak di sektor pertanian, sektor pertambangan, sektor perdagangan dan lain sebagainya. Di Indonesia orang atau pelaku usaha tersebut sebagian dalam memperoleh modal usaha dan juga kebutuhan sarana prasarananya diperoleh melalui bank atau juga diperoleh dari perusahaan pembiayaan yang sistem pembayarannya dilakukan dengan cara kredit. Dalam melaksanakan ikatan di dalam perkreditan antara debitur dan kreditur diikat oleh sebuah perjanjian yang di dalamnya menyangkut mengenai hak dan kewajiban dari masing-masing pihak. Berdasarkan pasal 1338 ayat ( 1) KUH Perdata menyatakan bahwa seluruh perjanjian yang telah disepakati berlaku syah sebagai Undang-undang bagi yang membuatnya. Dalam artian perjanjian tersebut dibuat untu k mengikat antara kedua belah pihak sehingga mereka diharuskan untuk mentaatinya termasuk perjanjian kredit antara kreditur dan debitur. Akan tetapi dengan adanya virus corona yang ada sejak 2019 lalu secara langsung berpengaruh terhadap perjanjian kredit di Indonesia karena banyak nasabah yang kehilangan pekerjaan sehingga banyak nasabah yang kesulitan untuk membayar kredit yang merupakan suatu kewajiban yang harus dipenuhi oleh nasabah.

Otoritas jasa keuangan terus membantu otoritas publik dengan memberikan ruang pada area bisnis termasuk miniatur dan usaha swasta untuk memfasilitasi kredit atau angsuran pembiayaan mereka dan mempermudah mendapatkan kredit atau pembiayaan dari bank dan perusahaan pembiayaan dengan diterbitkannya POJK No.11/POJK.03/2020 tentang Stimulus perekonomian nasional sebagai kebijakan. Dampak penyebaran corona virus disease yang mulai berlaku sejak 13 Maret 2020 sampai 31 Maret 2021. Dan ini adalah merupakan salah satu program jangka pendek yang dikeluarkan oleh pemerintah dalam memberikan perlindungan terhadap warganya. Maka untuk rnengetahui kedudu kan POJ K No.1 I/POJ K.03/2020. Penelitian ini bertujuan untuk menelaah pengaturan hukum penundaan kredit terhadap nasabah yang terdampak covid 19 di Indonesia dan menjelaskan perlindungan hukum terhadap nasabah yang terdampak cosvid 19 di Indonesia

\section{METODE PENELITIAN}

Penelitian ini disusun berdasarkan pendekatan hukum normatif yaitu dengan melakukan pengkajian atau analisis di setiap bahan-bahan hu kum dari literatur-literatur atau buku-buku dan peraturan Perundang-undangan yang memiliki kaitan dengan penelitian yang akan dibahas . Penelitian ini menerapkan dua jenis pendekatan penelitian, yakni pendekatan undang-undang dan pendekatan fakta. Pendekatan Perundang-undangan merupakan suatu pendekatan yang ditetapkan melalui cara menelaah peraturan perundang- undangan yang berkaitan dengan permasalahan hukum yang sedang dibahas (Waluyo, 2002). Maksud penggunaan pendekatan ini adalah pendekatan dengan produk legislasi dan regulasi yang merupakan putusan hasil dari terbitan oleh pejabat administrasi Negara yang bersifat konkret dan khusus. Pendekatan konsep adalah pendekatan yang dilakukan dengan asas-asas, doktrin-doktrin san atau teori-teori hu kum yang berhubungan dengan isu yang akan ditangani. Sumber data yang digunakan adalah bahan hukum primer dan sekunder yang doperoleh melalui teknik pencatatan dan arsip, selanjutnya setelah data terkumpul selanjutnya dianalisis secara kulitatif deskriptif (Sugiyono, 2013). 


\section{HASIL DAN PEMBAHASAN}

\section{Pengaturan Perlindungan Hukum Terhadap Nasabah dalam Penundaan Kredit di Indonesia}

Setiap individu atau substansi bisnis yang berupaya untuk memperluas kebutuhan yang efisien dan menguntungkan sangat membutuhkan subsidi, baik beru pa kredit, modal yang dimiliki perusahaan atau individu sebagian besar didapat melalui kredit usaha atau pinjaman modal dengan tujuan membantu ekspansi usahanya. Perbankan sebagai fondasi perantara moneter mengambil bagian penting dalam ukuran kemajuan publik. Undang-undang Nomor 8 Tahun 1999 tentang Perlindungan Konsumen juga sangat terkait, terutama sejauh asuransi yang sah untuk klien bank sebagai konsumen. Selain hal lainnya, adanya pemahaman kredit atau pembiayaan bank yang merupakan pengaturan standar .

Diidentifikasi dengan keamanan yang sah untuk klien karena nasabah perbankan adalah pengaturan sehubungan dengan sistem untuk penggabungan kondisi standar. Ketentuan standar adalah setiap pedoman atau ketentuan dan ketentuan yang telah diatur dan diputuskan sendiri oleh pelaku bisnis sebagaimana dituangkan dalam laporan atau pemahaman yang membatasi dan harus dipenuhi oleh konsumen. Pada tingkat khusus, payung hukum yang memastikan klien antara lain, pedoman sehubungan dengan tujuan protes klien dan intervensi keuangan internal melalui Peraturan Bank Indonesia (PBI). Dalam perjanjian kredit boikot debitur diartikan sebagai nasabah dalam bank tersebut, yang ditegaskan dalam Undang-undang Perlindungan Konsumen disamakan dengan konsumen, ini dapat dilihat dari Pasal I ayat (2) yang menegaskan bahwa Konsumen merupakan setiap orang yang menggunakan barang dagangan lain yang tersedia di ruang publik, baik untuk membantu diri sendiri, keluarga mereka, individu atau hewan hidup lainnya dan bukan untuk mengawasi.

Nasabah merupakan pengguna produk serta adrninistrasi yang diberikan oleh bank untuk tidak ditukar. Jadi untuk situasi ini, klien juga seorang pembelanja. pengertian jaminan pernbeli tertuang dalam pasal 1 angka 1 Undang-undang Nomor 8 Tahun 1999 tentang Asuransi Pembeli. Perlindungan konsumen merupakan langkah yang dilakukan oleh pemerintahan dalam menjamin kepastian hukum untuk memberikan jaminan kepada konsumen. Perlindungan hukum merupakan jaminan yang diberikan kepada subjek yang sah, khususnya orang atau benda yang sah sebagai instrumen, baik bersifat preventif maupun abusive, baik lisan maupun tertulis. Terdapat beberapa asas-asas penting dalam hu kum perjanjian. Asas-asas tersebut adalah sebagai berikut

a. Asas kebebasan berkontrak, terdapat dalam ketentuan Pasal 1338 ayat (I) K HPerdata, yang menegaskan bahwa, Semua perjanjian yang dibuat secara sah berlaku sebagai Undang-undang bagi para pihak yang membuatnya Semua perjanjian berarti setiap orang bebas membuat perjanjian yang isinya apa saja yang ia kehendaki (H.S \& Nurbani, 2013). Asas konsensualisme, asas ini dapat ditemu kan dalam rumusan Pasal 1320 Kitab Undang-undang Hukum Perdata. Konsensualisme artinya sepakat. Maksud dari asas konsensualisme adalah bahwa suatu perjanjian dan perikatan timbul karenanya itu sudah dilahirkan sejak detik tercapainya kesepakatan.

b. Asas kepercayaan, seorang individu yang melakukan kesepakatan biasanya diterapkan dengan melakukan pertemuan lain yang memupuk kepastian antara dua pertemuan bahwa satu sama lain akan tetap setia pada komitmennya, pada akhirnya, akan memuaskan prestasinya di kemudian hari.

c. Asas kekuatan mengikat, terikatnya suatu perjanjian yang tidak terbatas pada apa yang secara khusus disetujui, tetapi juga pada beberapa komponen lain selama kebiasaan dan kehormatan dan etika inginkan.

d. Asas persarnaan hukum, asas ini menempatkan pertemuan dalam korespondensi, tidak ada perbedaan, meskipun ada perbedaan dalam kulit, negara, kelimpahan, kekuatan, posisi, dll.

e. Asas Keseimbangan. Asas ini membutuhkan kedua belah pihak untuk memenuhi dan melaksanakan pengaturan tersebut. Pedoman keseimbangan ini merupakan kelanjutan dari aturan keadilan. Penyewa memiliki pengaruh untuk meminta pencapaian melalui kelimpahan peminjam, namun pemberi pinjaman juga menanggung beban untuk melakukannya sesuai dengan kesusilaan umum

f. Asas kepastian hukum perjanjian, sebagai sosok yang sah harus mengandung kepastian hukum. Kepastian ini terbongkar dari kekuatan yang membatasi pemahaman ini, lebih spesifiknya sebagai hukum pertemuan. 
g. Asas moral, asas ini bisa diperoleh dari sukarela sebagaimana diatur dalam Pasal $1354 \mathrm{KU}$ HPerdata sena dapat dilihat pada Pasal 1339 K UHPerdata yang memberi inspirasi kepada para peserta untuk melakukan pemahaman bahwa bukan hanya masalah yang diarahkan di dalamnya tetapi juga kecenderungannya dan kepatutan (moral).

h. Asas kepatutan, asas ini dituangkan dalam Pasal $1339 \mathrm{~K}$ UHPerdata asas kepatutan disini mengidentifikasi dengan pengaturan sehubungan dengan substansi pemahaman. Ukuran hubungan juga dikontrnl oleh perasaan ekuitas di mata publik.

Dengan adanya pengaturan mengenai perjanjian tersebut maka perjanjian kredit pun harus mengacu pada ketentuan-ketentuan yang dijelaskan di atas. Namun kredit di Indonesia mengalami suatu perubahan semenjak adanya covid 19 di Indonesia. Pemerintah sudah meminimalisir permasalahan ini dengan mengeluarkan kebijakan melalui otoritas jasa keuangan (OJK) yaitu Peraturan OJK Nomor 11 POJK.03 2020 tentang Stimulus Perekonomian Nasional Sebagai Kebijakan. Dampak Penyebaran virus pandemi 19. POJK Nomor 11 Tahun 2020 ini pada intinya memberikan stimulus keuangan sebagai ruang bagi masyarakat, termasuk pelaku usaha Mikro Kecil dan Menengah (UMKM) dan sektor jasa keuangan yang terkena dampak secara langsung mau pun tidak langsung akibat penyebaran covid 19. Kebijakan pemberian stimulus ini, meliputi kebijakan penetapan kualitas aset dan kebijakan restrukturisasi kredit atau pembiayaan. Kebijakan ini ditetapkan pada

a) Bank umum konvensional

b) Bank umum shariah

c) Unit usaha shariah

d) Bank perkreditan rakyat dan

e) Bank pembiayaan rakyat syariah

\section{Perlindungan Hukum Terhadap Nasabah Terdampak Cos id 19 di Indonesia}

Perlindungan hukum dicirikan sebagai jenis kegiatan pemerintah yang sah atau kegiatan yang diberikan kepada subjek hukum sesuai dengan hak dan komitmen mereka yang dilakukan tergantung pada hukum tertentu di Indonesia (Sitorus, 2015). Keamanan yang sah muncul dalam hubungan yang sah. Hubungan yang sah adalah hubungan antara subjek yang sah yang memiliki kepentingan yang sah atau memiliki hasil yang sah (timbulnya hak dan kewajiban) (Soeroso, 2006). Hubungan hukum tersebut dilakukan antara subyek hukum, baik manusia badan hukum maupun jabatan ambt) perlindungan hukum dicirikan sebagai jenis kegiatan pemerintah yang sah atau kegiatan yang diberikan kepada su bjek hu kum sesuai dengan hak dan komitmen mereka yang dilakukan tergantung pada hu kum tertentu di Indonesia. Keamanan yang sah muncul dalam hu bungan yang sah. Hubungan yang sah adalah hubungan antara subjek yang sah yang memiliki kepentingan yang sah atau memiliki hasil yang sah (Milayani, 2017).

Secara umum sehubungan dengan nasabah yang terdampak cosvid 19 pemerintah telah memberikan perlindungan hukum yakni dengan dikeluarkannya peraturan berupa peraturan otoritas jasa keuangan yakni Peraturan Otoritas Jasa Keuangan Nomor 11 POJK.03 2020 tentang Stimulus Perekonomian Nasional Sebagai Kebijakan. Dampak Penyebaran covid 2019. Peraturan ini adalah salah satu bentuk produ $\mathrm{k}$ hukum pemerintah dalam memberikan perlindungan terhadap nasabah yang terdampak covid 19 di Indonesia. Menyatakan bahwa terdapat dua jenis perlindungan hukum, yaitu perlindungan hukum represif dan perlindungan hukum preventif (Hadjon, 1987). Preventif artinya rakyat diberi kesempatan untuk mengajukan permohonan keberatan atau penilaiannya sebelum pilihan badan publik mengambil struktur yang konklusif. Untuk situasi ini, ini menyiratkan bahwa keamanan preventif yang sah ini dimaksudkan untuk mencegah pertanyaan. Melalui perlindungan hukum secara preventif maka otoritas publik didorong untuk berhati-hati dalam mengambil keputusan, karena asuransi yang sah secara preventif menyiratkan banyak sekali kegiatan pemerintah yang bergantung pada peluang kegiatannya (Siska et al., 2019).

Perlindungan hukum represif merupakan perlindungan akhir karena otorisasi seperti denda, penahanan, hadiah tambahan yang disiapkan untuk konteks atau pengaturan telah dilakukan. Keamanan sah yang keras ini berarti menentukan perdebatan yang sebanding dengan asuransi klien terdampak covid 19 pemerintah juga telah memberikan perlindungan melalui beberapa peraturan Perundang-undangan. Dalam simpan pinjam selama Pandemi ini, otoritas publik memilih untk 
menggunakan instrurnen pembangunan kembali sesuai arahan POJK NO. II/POJ K.03/2020, meskipun penjadwalan ulang dan rekondisi juga tidak dibatasi, hal itu bergantung pada selera dan keputusan pemegang utang. Untuk saat ini, UU PKPU merupakan pedoman terlengkap untuk mendorong pemulihan kewajiban individu yang berhutang kepada pemberi pinjaman. Tiga langkah pembangunan kembali yang adalah sebagai berikut

1. Langkah periama yang harus dilakukan dalam upaya pembangunan kembali adalah rnengarahkan evaluasi batas usaha yang kemudian dikontraskan dengan komitmen yang ada. Pembangunan kembali digunakan untuk rnenghubungkan kemampuan bisnis dengan komitmen yang ada. Ketika pembangunan kembali tidak dapat menghu bungkan kapasitas dengan komitrnen, pembangunan kembali akan gagal, dan organisasi akan mendorong likuidasi.

2. Langkah kedua adalah merealisasikan proyeksi dalam proposisi yang diajukan kepada laser dengan maksud agar kewajiban dapat dikendalikan. Pembangunan kembali yang layak mendorong pemegang utang menjadi pengatur kewajiban, namun pembangunan kembali yang tidak memenuhi syarat sangat menernpatkan posisi kewajiban sebagai pengatur pemegang utang.

3. Langkah ketiga adalah mencatat konsekuensi pembangunan kembali sebagai pemahaman atau jika diambil strategi yang sesuai, ditempatkan sebagai pilihan pengadilan. Kemajuan yang tepat ini sangat penting untuk menjamin keyakinan yang sah untuk pembangunan kembali.

Cara di atas memang tidak semudah yang dibayangkan, di mana kemampuan yang sah dan terperinci diperlukan gambaran bisnis yang hati- hati. Meski begitu, saat ini tidak ada alternatif lain untuk menyelamatkan area bisnis, di mana pembangunan kembali adalah langkah utama.

\section{SIMPULAN DAN SARAN}

\section{Simpulan}

Dari analsis data di atas maka dapat disimpulkan bahwa Secara umum pengaturan penundaan kredit terhadap nasabah terdampak covid 19 diatur dalam Peraturan Otoritas Jasa Keuangan Nnmor 11 POJK.03 2020 tentang Stimulus Perekonornian Nasional Sebagai Kebijakan dampak Penyebaran Covid 19. Perlindungan hukum terhadap nasabah yang terdampak covid 19 di indonesia ada dua yaitu perlindungan hukum presentif yakni dengan menerbitkan PERPU Nomor I Tahun 2020 tentang kebijakan keuangan negara dan stabilitas untu k penanganan pandemi coronavirus disease 19 dan atau dalam rangka menghadapi ancaman yang membahayakan perekonomian nasional dan atau stabilitas sistem keuangan dan Perlindungan hukum represif yakni berpedoman pada Surat Edaran Bank Indonesia No. 26/4/BPPP yang dikeluarkan pada 29 mei 1993 yang pada prinsipnya rnengatur penyelamatan kredit bermasalah sebelum diselesaikan melalui lembaga hukum atau badan alternatif lainnya.

\section{Saran}

Sesuai dengan simpulan penelitian di atas, adapun saran yaitu diharapkan kepada perusahaan, dalam proses penundaan kredit perusahaan diharapkan melaksanakan amanat dari aturan POJK. Bagi Pemerintah, melakukan pengawasan terhadap proses dan penanganan penundaan kredit terhadap nasabah yang terdarnpak covid 19 agar setiap kebijakan yang dikeluarkan sesuai dengan tujuan yang diharapkan.

\section{DAFTAR PUSTAKA}

H.S, S., \& Nurbani, E. S. (2013). Penerapan Teori Hukum pada Penelitian Tesis dan Disertasi. Jakarta: Rajawali Pers.

Hadjon, P. M. (1987). Perlindungan Hukum Bagi Rakyat Indonesia. PT. Bina llmu. Surabaya.

Hairi, P. J. (2018). Konsep dan Pembaruan Residivisme dalam Hukum Pidana di Indonesia. Negara Hukum, 9(2), 199-216.

Milayani, O. (2017). Kedudukan Hukum Ahli Waris yang Mewaris dengan Cara Mengganti Atau Bij Plaatsvervulling' Menurut Burgerlijk Wetboek. Al' Adi, 9(3), 405-434.

Siska, S. N. L. P., Putra, A. I. B., \& Wiratni, D. A. . S. (2019). Perlindungan Hukum terhadap Pelaku Usaha Online Shop Apabila Terjadi Wanprestasi Yang Dilakukan oleh Pemberi Jasa Endorse di Kota Denpasar. Journal Ilmu Hukum, 7(4), 1-19.

Sitorus, R. (2015). Perlindungan Hukum Terhadap Nasabah Kartu Kredit Ditinjau dari UndangUndang Nomor 8 Tahun 1999 tentang Perlindungan Konsumen. Lex Privatum, 3(1), 232-239.

Soeroso, R. (2006). Pengantar Ilmu Hukum. Sinar Grafika. 
Sugiyono. (2013). Metode Penelitian Pendidikan Pendekatan Kuantitatif dan Kualitatif. Alfabeta.

Suputra, K. P., Wahyuni, M. A., \& Herawati, N. T. (2017). Analisis Strategi Penarikan Kredit Macet sebagai Faktor Kunci Berdirinya Kembali Lembaga Perkreditan Desa (LPD). Jurnal Ilmiah Mahasiswa Akuntansi Undiksha, 7(1), 11-22.

Waluyo, B. (2002). Penelitian Hukum Praktek. Sinar Grafika.

Yantie, V. D., Noor, I., \& Mindarti, L. I. (2017). Implementasi Program Bantuan Pemberian Kredit dalam Upaya Meningkatkan Produktivitas Kerja Pedagang Sayur. Jurnal Administrasi Publik, 1(2), 299-308. 